any sudden, radical reform; sustained evolution seems a surer, more predictable way forward. And several speakers pointed to the paradoxical contrast between Mr Clarke's gung ho approach and the standard teaching on the way competent management should introduce change-by involving the workforce in the analysis of the defects and in the planning of change and by piloting new proposals before introducing them full scale.

In effect, doctors are telling the government that its treatment will not work for the most basic of reasons in medicine - the diagnosis is wrong. The government says that it believes that the problems of the NHS are due to the absence of competition and that the solution will come from rearranging matters so that market forces can operate, when efficiency will be so improved that all will be well. This analysis is based on political convictions and cost saving considerations rather than on any solid evidence.

The BMA's diagnosis - in line with the Joint Consultants Committee, the Royal College of Nursing, the House of Commons social services committee, and virtually every informed medical institution - is that the system is simply underfunded. Of course efficiency could be further improved in any organisation of the size of the NHS, and some changes are needed-especially in finding ways for money to follow patients so that hospitals that improve their productivity benefit from their efforts. And one real gain from current attempts to quantify and cost medical services should be a realistic assessment of how much more is needed to fund a comprehensive, competent system. Probably the answer will be not very different from the $8 \%$ of gross national product that is the current medical guesstimate.

Mr Clarke's immediate response to the BMA's call for negotiations on the principles of the white paper was to ask the BMA for its plans. This is a challenge that doctors should accept. In fact the BMA has already made, in concert with nurses and managers, a cogent case for more funding. ${ }^{4}$ Even so, theire does seem a growing consensus among the NHS health professions that the NHS needs in addition a sort of bill of rights, perhaps along the lines of the manifesto produced by the Birmingham Consultants for the Rescue of the NHS (p 1411).

At least six months must now elapse before parliament could begin to debate any of the primary legislation required for the white paper to become law. In that period the BMA hopes by talking to persuade the government to change its approach. It should, we believe, also lead a campaign setting out a specific alternative programme for the future of the NHS - one that can be supported by a broad consensus of doctors, nurses, and managers.

TONY SMITH

Deputy editor, $B M \mathcal{F}$

1 Secretaries of State for Health, Wales, Northern Ireland, and Scotland. Working for patients. London: HMSO, 1989. (Cmnd 555.)

2 Anonymous. Underfunding: latest estimates. Br Med f 1989;298:1339.

3 Department of Health and Social Security. Health services management. Resource managemen (management budgeting) in health authorities. London: DHSS, 1986. (HN (86)34.)

4 O'Higgins $M$. Health spending - a way to sustainable growth. A report commission by the Instituc

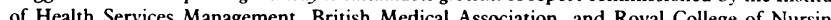
London: IHSM, 1987.

\title{
... Sends the GPs' contract out for consultation
}

\section{LMC conference will decide on "commended" contract package}

General practitioners now have to decide whether to approve their revised contract or reject it. Do the improvements achieved by Dr Michael Wilson and the negotiators from the General Medical Services Committee outweigh those changes on which the Secretary of State has not budged? The improvements include more realistic criteria for availability and for the basic practice allowance, the preservation of the seniority allowance, a relaxation in the conditions for differential night visit fees, the removal of rural practice funding from the contract discussions, and more sensible targets for immunisation and cervical cytology screening. Among $\mathrm{Mr}$ Kenneth Clarke's sticking points are his extension of capitation based payments, a financial penalty on the use of deputising services at night, the loss of group practice allowances, and an insistence on targets for preventive activities. The paper now being sent to all general practitioners by the GMSC gives them an opportunity to assess the reviewed contract package (20 May, p 1387).

In a foreword to that paper Dr Wilson, chairman of the GMSC, gave one reason why the negotiators commended this package: "We firmly believe the choice is between the implementation of an agreed package or the imposition of contractual changes unilaterally by the Secetary of State." That is a stark choice and some speakers at what may be one of the most important meetings of the General Medical Services Committee (p 1457) since the 1966 Family Doctors Charter agreement would have preferred an imposed contract rather than the package commended by Dr Wilson and the GMSC negotiators. Those speakers came from local medical committees which had reacted briskly to the announcement on
4 May of that commended agreement; they were convinced that the negotiators had thrown away a strong bargaining position built on the profession's near unanimous opposition to the new contract announced in February by Kenneth Clarke. ${ }^{1}$

Understandably, the chairman of the GMSC rejected such accusations but admitted that the agreed proposals were not the list that he or the committee would have chosen. On the other hand, nor were they the list that the Secretary of State would have selected. They were, as is inevitable in negotiations, a compromise, and in a persuasive performance during a five hour debate in the GMSC on 18 May Dr Wilson left none of his audience in doubt that he saw the package as a considerable practical advance on Kenneth Clarke's original contract proposals.

The intense opposition among doctors to increasing the proportion of remuneration from capitation fees has been based on fear of a return to the head hunting of precharter practice. But as Dr Wilson pointed out the proportion of income from capitation fees would be $55 \%$ (not $60 \%$, which includes capitation based income), a figure that is almost identical with the figure in 1967, when the Family Doctor Charter was introduced. Furthermore, until the review body prices the new contract in April 1990 precise comparisons are difficult.

Negotiators are in an unenviable position when having to decide during the heat of negotiations whether the end of the road has been reached. The GMSC's experienced team were convinced on 4 May that the concessions obtained were as much as they were going to squeeze out of a government that has a massive parliamentary majority and a determination to 
make general practitioners' contracts more work sensitive. Finally, there was a strong case for settling the new contract so that the profession would be free to concentrate on the NHS review and its potentially damaging effects on the health service.

Much of the doctors' anger has arisen because of a belief that the revised contract was a fait accompli. That is wrong. Although the negotiators agreed to commend the package to general practitioners, the Secretary of State was told that a final decision on agreement or rejection rested with the conference of representatives of local medical committees on 21 and 22 June. Dr Wilson and his colleagues were understandably upset that doctors and local medical committees had jumped to conclusions before assessing the detailed contents of the package or hearing his briefing on the background to the negotiations. Certainly, many GMSC members who had come prepared to bury the package returned to their constituencies persuaded that it was worth unwrapping.

Doctors have also criticised the seeming hastiness of the 4 May agreement. But the seeds of this contract were planted in 1980 on the initiative of the local medical committee conference, which approved a new charter for general practice. ${ }^{2}$ Repeated attempts by the GMSC to negotiate changes in general practitioners' contracts were thwarted by policies to contain public expenditure and by repeated government promises of a green paper on primary care. The promise eventually materialised in November 1987 as the white paper Promoting Better Health, ${ }^{3}$ negotiations on which started in March 1988 and culminated in February 1989 with Kenneth Clarke's new contract. So when the two sides met on 4 May for what was expected to be the first of several ministerial level meetings each side was thoroughly grounded on the other side's views and aspirations. Unexpected progress was madeperhaps influenced by outside political events - and both sides took the opportunity to put a package together.

An understanding of the details and background of the package are essential if doctors are to reach a constructive decision in June. Doctors should recognise, too, the political importance of resolving the contract dispute because there are some highly damaging prospects for general practice in the white paper Working for Patients. ${ }^{4}$ The profession needs a clear field of fire to win that battle: Dr Wilson and his colleagues have provided an opportunity to ensure this.

Deputy editor, $B M \mathcal{F}$

GORDON MACPHERSON

\footnotetext{
1 Department of Health and Welsh Office. General practice in the National Health Service. A new contract. London: DoH, 1989.

New Charter Working Group. Report. London: GMSC, 1979.

3 Secretaries of State for Social Services, Wales, Northern Ireland, and Scotland. Promoting better health. London: HMSO, 1987. (Cmnd 249.)

Secretaries of State for Health, Wales, Northern Ireland, and Scotland. Working for patients. London: HMSO, 1989. (Cmnd 555.)
}

\section{Genetic factors in hyperactivity}

\section{Account for about half of the explainable variance}

Whereas parents use "hyperactivity" as a label for a broad range of childhood behaviours, including normal exuberance and frequent night wakenings, child psychiatrists employ the term to refer to restlessness and inattentiveness that are inappropriate for the child's age. ${ }^{1}$ Hyperactivity in this restricted sense is commonly accompanied by other cognitive, educational, and psychiatric handicaps ${ }^{1}$ and may affect about $1 \%$ of British primary school children. ${ }^{2}$

Family, adoption, and twin studies all suggest that genetic factors are important in hyperactivity..$^{3-11}$ Thus one large study found that maternal half siblings who grew up together were considerably less alike in measures of hyperactivity than full siblings. ${ }^{3}$ Another study of siblings who had been fostered separately found that concordance for hyperactivity was much lower for half siblings than for full siblings. ${ }^{4}$ When compared with the parents of children who were not hyperactive the biological parents of hyperactive children were more likely to have attentional problems in adult life, and they were also more likely (as judged by parental recall) to have been hyperactive themselves as children. ${ }^{67}$

Adoption studies suggest that these cross generational continuities reflect genetic rather than cultural transmission. Thus no excess of attentional problems or retrospectively diagnosed hyperactivity has been found in the adoptive parents of hyperactive children who were adopted when they were very young..$^{5-7}$ Twin studies also point to a genetic contribution: monozygotic twins are more alike than dizygotic twins of the same sex in measures of hyperactivity and inattention. ${ }^{89}$ Even when allowance has been made for parents' and teachers' tendencies to exaggerate the similarity of identical twins or minimise the similarity of non-identical twins, genetic factors account for about half of the explainable variance in hyperactivity. ${ }^{9}$ As the remaining half is presumably environmental this finding emphasises that both genetic and environmental effects are important.

Little is known about how hyperactivity is inherited, although some evidence favours polygenic transmission. ${ }^{1011}$ Different modes of inheritance may operate in different families as hyperactivity is probably caused by many different genetic disorders. Among the mentally retarded, for instance, hyperactivity is associated with several genetic conditions, including tuberous sclerosis, mucopolysaccharidoses, and untreated phenylketonuria. ${ }^{12}$ Hyperactivity without mental retardation may also be genetically heterogeneous. For example, some hyperactivity in non-retarded children may be caused by the gene (or genes) responsible for schizophreniathereby explaining why schizophrenia is commonly preceded by childhood inattentiveness ${ }^{13}$ and why the children of parents with schizophrenia have a particularly high rate of attentional problems. ${ }^{14}$

The knowledge that genes play an important part in hyperactivity is relevant to clinical practice. When faced with a hyperactive child doctors should remember that the parents' child rearing techniques are not necessarily to blame. Indeed, the parents may well deserve credit for how well they have coped with the child's severe and often exasperating handicap.

As is well shown by phenylketonuria, the fact that a disorder has a genetic component is not necessarily a cause for therapeutic pessimism. When more is known about which psychological factors influence hyperactivity it will be possible to look for clinically important interactions between genes and the environment. If psychosocial factors either amplify or suppress a genetic predisposition to hyperactivity 